University of Nebraska - Lincoln

DigitalCommons@University of Nebraska - Lincoln

\title{
The relative influences of climate and catchment processes on Holocene lake development in glaciated regions
}

\author{
Sherilyn C. Fritz \\ University of Nebraska-Lincoln, sfritz2@unl.edu
}

N. J. Anderson

Loughborough University, Loughborough, UK, N.J.Anderson@lboro.ac.uk

Follow this and additional works at: https://digitalcommons.unl.edu/geosciencefacpub

Fritz, Sherilyn C. and Anderson, N. J., "The relative influences of climate and catchment processes on Holocene lake development in glaciated regions" (2013). Papers in the Earth and Atmospheric Sciences. 381.

https://digitalcommons.unl.edu/geosciencefacpub/381

This Article is brought to you for free and open access by the Earth and Atmospheric Sciences, Department of at DigitalCommons@University of Nebraska - Lincoln. It has been accepted for inclusion in Papers in the Earth and Atmospheric Sciences by an authorized administrator of DigitalCommons@University of Nebraska - Lincoln. 
Published in Journal of Paleolimnology 49 (2013), pp. 349-362; doi: 10.1007/s10933-013-9684-z

(Special issue: A celebration of Prof. Rick Battarbee's contributions to palaeolimnology, edited by Holmes et al.)

Copyright () 2013 Springer Science+Business Media Dordrecht. Used by permission.

Submitted June 13, 2012; accepted January 23, 2013; published online February 27, 2013.

\title{
The relative influences of climate and catchment processes on Holocene lake development in glaciated regions
}

\author{
Sherilyn C. Fritz \\ Department of Earth and Atmospheric Sciences, University of Nebraska-Lincoln, \\ Lincoln, NE 68588-0340, USA; email sfritz2@unl.edu (Corresponding author)
}

\author{
N. J. Anderson \\ Department of Geography, Loughborough University, \\ Loughborough LE11 3TU, UK; email N.J.Anderson@lboro.ac.uk
}

\begin{abstract}
Following deglaciation, the long-term pattern of change in diatom communities and the inferred history of the aquatic environment are affected by a hierarchy of environmental controls. These include direct climate impacts on a lake's thermal and hydrologic budgets, aswell as the indirect affects of climate on catchment processes, such as weathering, soil development, microbial activity, fire, and vegetation composition and productivity, which affect the transfer of solutes and particulates from the terrestrial ecosystem into the lake. Some of these catchment influences on lacustrine systems operate as time-dependent patterns of primary succession that are set in motion by glacier retreat. This paper provides a conceptual model of some dominant pathways of catchment influence on long-term lake development in glaciated regions and uses a series of paleolimnological examples from arctic, boreal, and temperate regions to evaluate the relative role of direct climate influences and of catchment processes in affecting the trajectory of aquatic ecosystems during the Holocene in different environmental contexts.
\end{abstract}

Keywords: Diatom, Ontogeny, Succession, Paleoclimate, Catchment, pH, Nutrients, DOC

\section{Introduction}

A hierarchy of environmental controls that change with time drives variation in lake ecosystemstate over periods of decades to millennia (Figure 1). Climate is a first-order control on aquatic structure and function via a complex series of direct and indirect mechanisms. These include direct impacts on a lake's thermal and hydrologic budgets and the resultant influences on biogeochemistry and organisms, as well as the direct impacts of temperature on metabolic rates of aquatic organisms. Climate also influences lake ecosystems indirectly by affecting catchment structure and function, including weathering, soil development, microbial activity, fire, and vegetation composition and productivity, which, in turn, influence the transfer of solutes and particulates from the terrestrial system into the lake. In glaciated landscapes, where glacial retreat sets in motion a sequence of change associated with primary succession, these catchment processes can be time-dependent; this directional series of changes is commonly referred to as ontogeny (e.g. Battarbee 1991; Engstrom et al. 2000 and references therein).

Here we consider the role of catchment processes on long-term lake evolution during the Holocene 


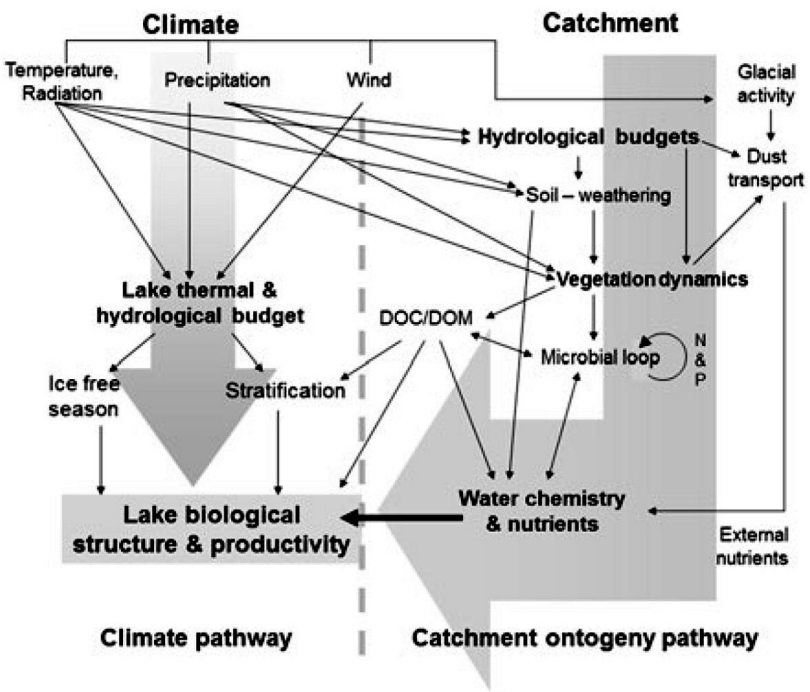

Figure 1 A conceptual model showing direct climate forcings and catchment-mediated processes that affect biological community structure and productivity. Details of the processes and their ecological affects are summarized in Table 1, together with relevant examples from the literature.

(Table 1). We review both climate-driven changes in terrestrial structure and function and time-dependent successional processes that affect weathering, soil development, hydrology, and nutrient cycling hence catchment processes that have the potential to alter the fluxes of materials to lakes embedded within the landscape. Although we recognize the over-arching influence of climate on aquatic ecosystem dynamics (Battarbee 2000), we focus on indirect catchmentmediated processes, which filter the influence of natural climatic variability (Leavitt et al. 2009). We also present examples from the paleolimnological literature that illustrate the role of these catchment processes in a range of environments and evaluate settings where catchment processes are likely to be most important relative to settings where direct climate impacts dominate changes in ecosystem structure and function. We focus our review on lakes formed by glaciation and therefore on landscapes where primary succession following ice retreat interacts with climate to affect lacustrine ecosystem state. We also focus our review primarily on studies that infer ecosystem changes from sedimentary diatom assemblages.

\section{Biogeochemical linkages between lakes and their catchments}

Catchment processes that affect aquatic ecosystems include changes in hydrology, weathering, veg- etation, and microbial dynamics, which in turn influence various biogeochemical pathways that link the catchment and the lake (Figure 1; Table 1). Some processes involve direct temperature or hydrological impacts on chemical weathering of parent material or on the character of soils in influencing the chemistry of surface waters; others involve changes in composition and biomass of vegetation or the microbial community, which subsequently alter soils, hydrology, and biogeochemical cycling.

The impacts of chemical weathering and vegetation change on base cations, $\mathrm{pH}$, and dissolved organic carbon

Long-term natural acidification of lakes is common in regions with base-poor bedrock (Bigler et al. 2002; Engstrom et al. 2000; Ford 1990; Renberg 1990; Whitehead et al. 1989). Early studies of lake ontogeny posited that lakes become more acidic over time, because of the progressive leaching of base cations from soils (Iverson 1964; Whitehead et al. 1989). More recent studies from boreal and temperate forests dominated by conifers suggest that longterm lake acidification may be more tightly linked to vegetation change and its impacts on soil development and hydrology. The accretion of soil organic matter (SOM) over time increases the flux of dissolved organic carbon (DOC) in runoff, with consequent influences on the acid-base chemistry of down-gradient lakes (Pienitz et al. 1999). Podzolization in organic-rich soils also reduces hydrologic conductivity, groundwater recharge, and consequently the influx of base cations in groundwater inflow (Engstrom et al. 2000; Ford 1990). The net effect of the alteration of hydrological flow paths is to increase surface flow through organic-rich soils. Thus, in a variety of basepoor terranes the increased surface flux of organic acids and decreased flux of base cations in groundwater produces a net decline in lake $\mathrm{pH}$ over time. These processes operate in the cool humid forested areas of boreal and temperate regions, as well as in the treeless areas of arctic and sub-arctic regions, despite the lower plant biomass and shallower soils.

DOC transfer from land to lakes also has the potential to have profound limnological effects on the underwater light climate (Williamson et al. 1999), thermal budgets (Fee et al. 1995), other elemental cycles, and trophic interactions (Karlsson et al. 


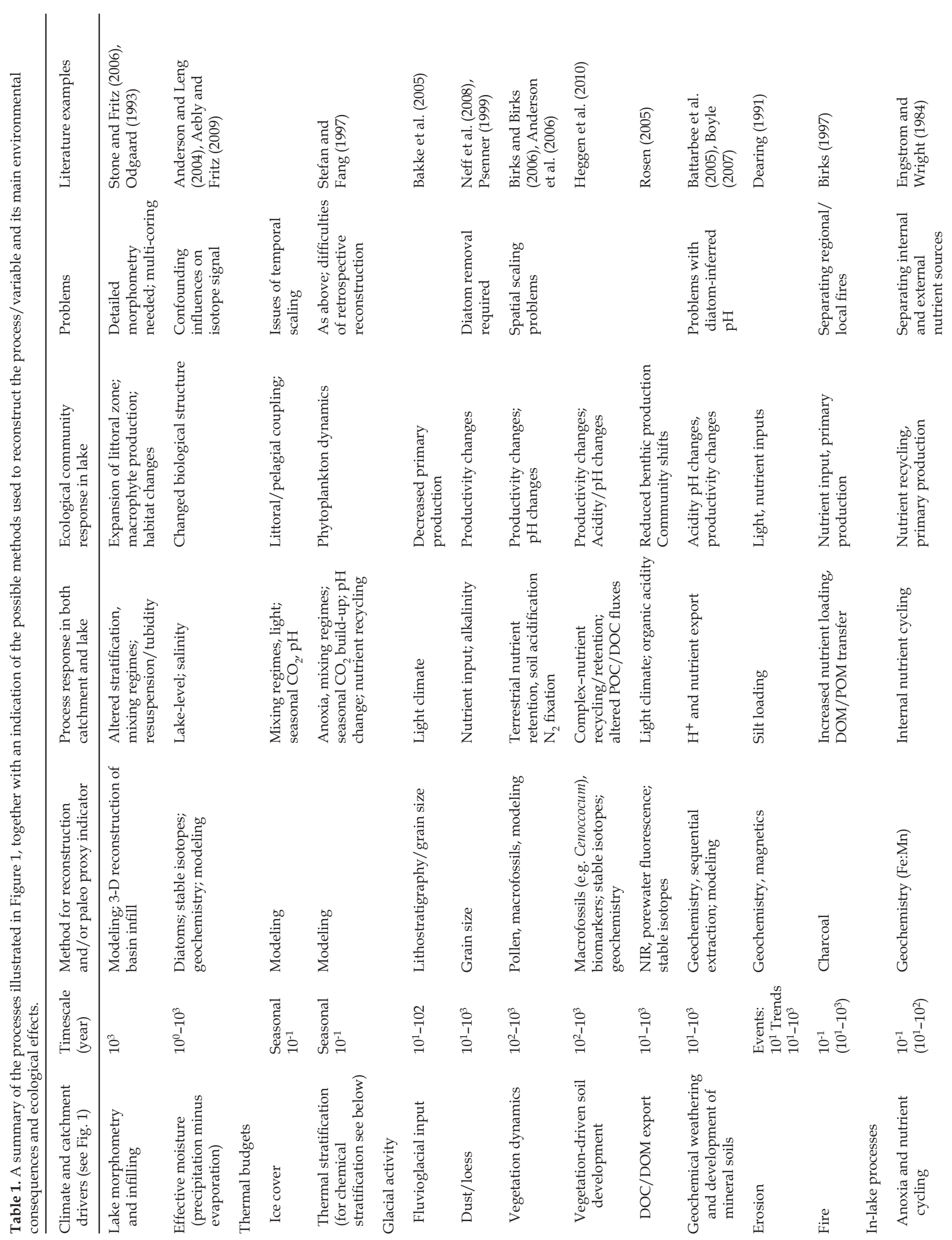




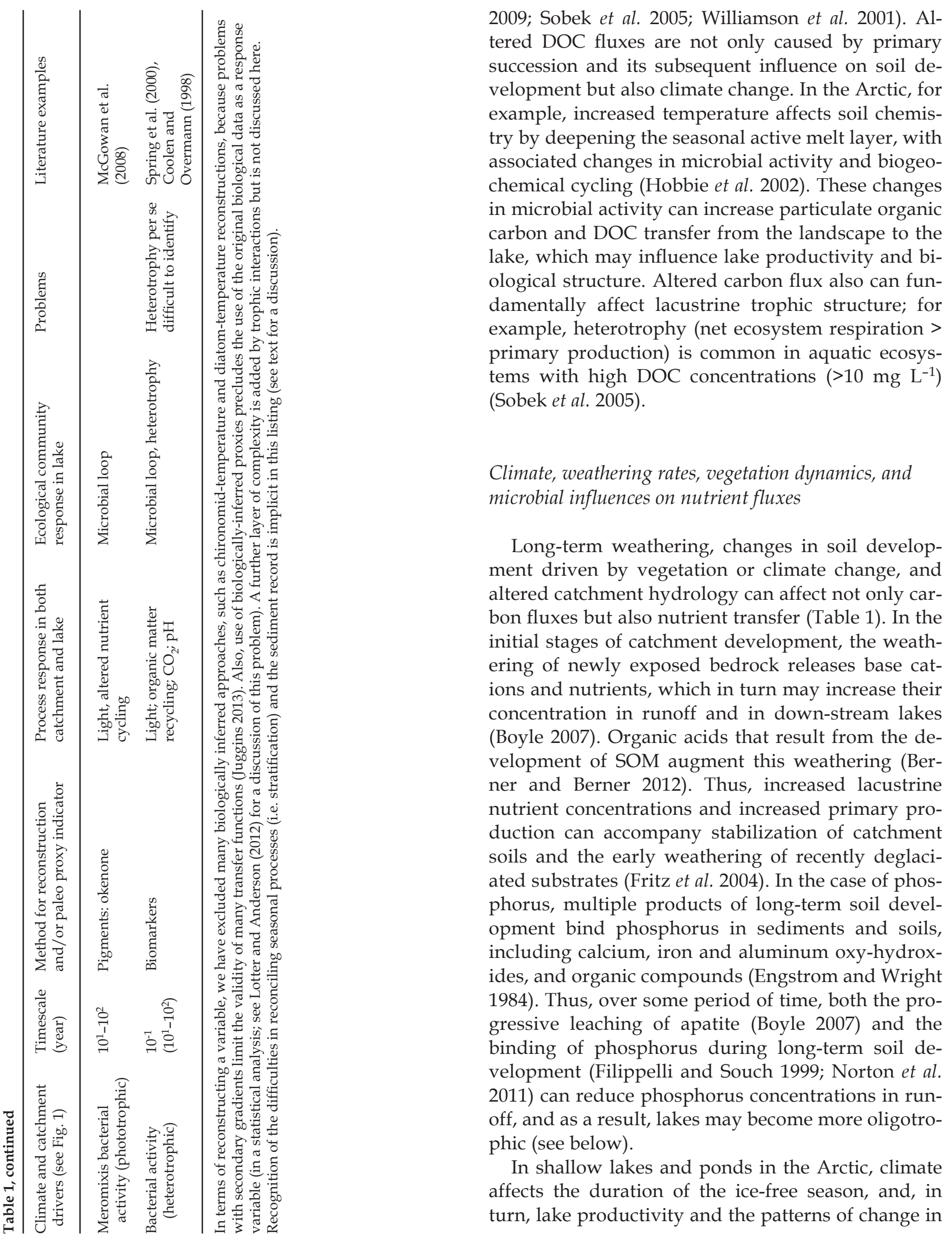


lacustrine diatom assemblages ( $\mathrm{Smol}$ and Douglas 2007). Yet, seasonal and inter-annual changes in temperature, hydrology, and chemical weathering that affect nutrient fluxes and hence primary production may be equally important as drivers of ecological change. Jones et al. (2005) reported elevated nitrogen export from areas with discontinuous permafrost, a study that has clear implications for lake-catchment interactions in a warming world. Even in dry arctic environments, such as the interior of SW Greenland, where summer precipitation is insufficient for overland flow (Hasholt and Søgaard 1978), the period of spring melt is a significant contributor to lacustrine nutrient budgets (cf. Tye and Heaton 2007). Although chemical weathering in sparsely vegetated catchments of the high Arctic and in the fellfield landscapes at higher altitudes in the low Arctic is poorly understood, its role in surface-water chemistry merits more attention (Hall et al. 2002), particularly its potential to influence nutrient budgets of oligotrophic lakes.

The biomass and composition of catchment vegetation also influence nutrient fluxes from catchments into lakes by influencing microbial processes (Table 1). Microbial nitrogen fixation in soils is enhanced by several early successional plant species, such as Dryas and Alnus (Chapin et al. 1994), and by cyanobacteria. In arctic ecosystems today, estimates suggest that $25-80 \%$ of nitrogen inputs to soils is due to fixation (Chapin and Bledsoe 1992). If terrestrial uptake does not consume the resulting soil pools of ammonium and nitrate, nitrogen export may increase during the early stages of terrestrial succession, in turn increasing primary production in nitrogen-limited aquatic ecosystems (Engstrom et al. 2000; Fritz et al. 2004; Goldman 1961; Hu et al. 2001). Vegetation development also can affect aquatic nitrogen availability by altering the flux of SOM to the lake and in turn affecting sediment redox and denitrification (Seitzinger et al. 2006).

Nitrogen export from catchments is influenced by rates of microbial processing and by direct uptake by plants, both of which are influenced by climate via a complex set of linkages. Plant phenology, both timing of the spring growth and of late-season senescence, can determine nitrogen uptake, loss to soil water, and hence nitrogen availability for utilization in aquatic systems. There is growing evidence for nitrogen mineralization during winter, with substantial inorganic nitrogen export from terrestrial systems during snowmelt, because terrestrial plants are unable to utilize the plant available $\mathrm{N}$ pool early in the season. Tye and Heaton (2007) found that soil-derived $\mathrm{NO}_{3}$ loss increased in the late summer in tundra on Svalbard, possibly associated with reduced demand by plants during their late-season senescence. Although enhanced microbial activity associated with increased temperatures in late-season may increase $\mathrm{NO}_{3}$ loss, continued warming may reduce its impact due to positive effects on plant growth and seasonality, possibly over-riding photoperiod (Tye and Heaton 2007). Changes in vegetation composition driven by climate change also can affect nitrogen fluxes. Thus, the greening of the Arctic - the expansion of shrubby vegetation across previously bare ground (Tape et al. 2006) - is likely to sequester nutrients in plant biomass, as well alter hydrology and other biophysical processes locally. The implications of these processes for lake nutrient budgets are, therefore, complex. A further complication for predicting catchmentlake nitrogen interactions is that greater nitrogen mineralization results in a positive feedback on decomposition rates, because the enhanced nitrogen inputs relieve bacterial N-limitation. Another level of complexity is that of catchment spatial heterogeneity (Hobbie et al. 2002) and the importance of site characteristics and successional stage (which influence plant growth and vegetation composition, which in turn control nutrient stoichiometry and the build-up of nutrient pools in soils, cf. Wookey et al. 2009). These processes vary considerably at the regional and local scale, and this heterogeneity can impart considerable variability to downgradient lacustrine systems. This complexity needs to be fully considered in paleolimnological analyses and incorporated into multi-site paleolimnological studies (e.g. Fritz et al. 2004; Figure 2).

\section{Long-term patterns of ecosystem change}

Below we review a series of examples from arctic, boreal, and temperate regions to evaluate the relative role of direct climate influences and of catchment processes (Figure 1) in affecting the Holocene trajectory of aquatic ecosystem structure and function over time. Specifically, we evaluate (1) the settings in which changes in acid-base status driven by catchment processes are the first order influence on aquatic structure and function; (2) changes in nutrient status 


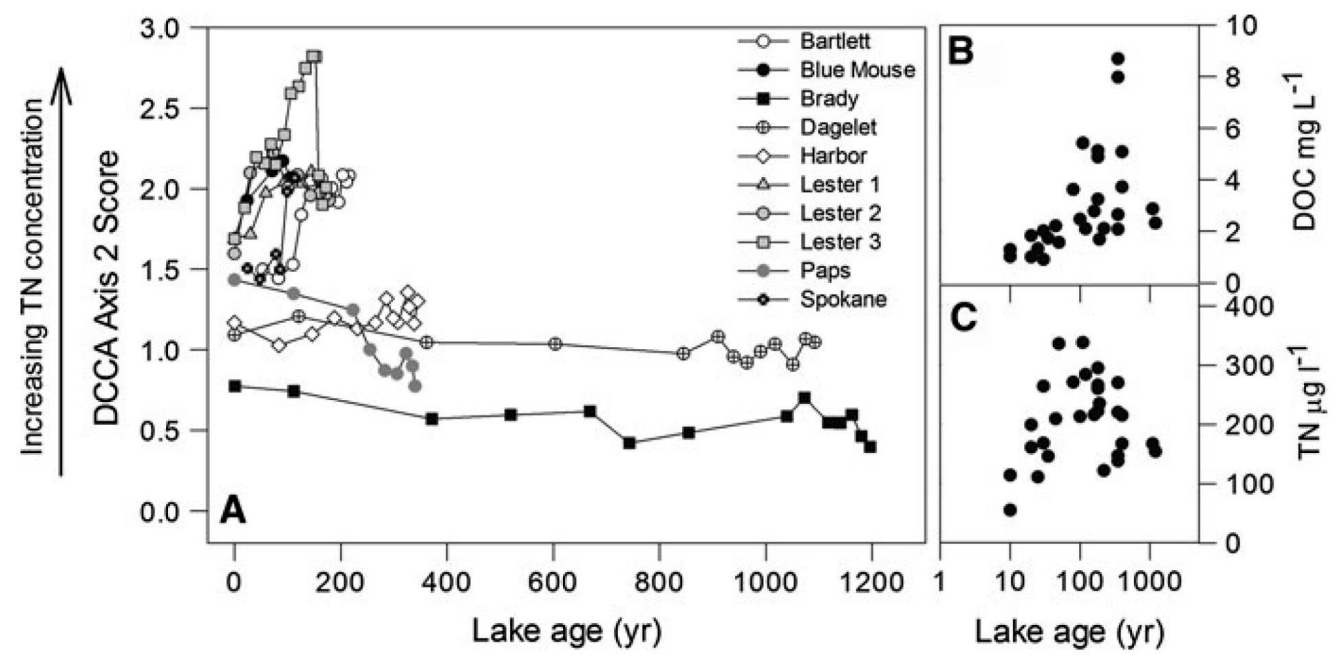

Figure 2. Spatial variability in developmental trends inferred from diatom assemblages in short cores from a chronosequence of lakes in Glacier Bay Alaska highlighting the complex response of lakes within a small geographic area. a) The diatom assemblage trajectory along the nutrient (nitrogen) axis (DCCA2, $\lambda=0.37$ (axis $1 \lambda=0.63$ ), see Fritz et al. 2004) since the time of lake formation by retreating glaciers; $\mathbf{b}$ ) contemporary lakewater DOC concentration plotted against lake age; c contemporary lakewater TN concentration plotted against lake age. Some lake trajectories vary very little on axis 2 but show change in inferred DOC (e.g. Brady, cf. b) whereas other lakes, e.g. Lester-3, do change along the N-concentration gradient, reflecting the changing TN gradient observed in contemporary chronosequence (c). See Fritz et al. (2004) for the diatom stratigraphies and additional information.

and productivity associated with primary catchment succession; (3) the relative role of direct climate influences versus catchment mediated changes in nutrient status in affecting the development of planktic diatom floras; and (4) settings where climate is the primary driver of long-term limnological change.

\section{Long-term changes in $\mathrm{pH}$ and dissolved organic carbon in arctic and boreal lakes}

Interactions among catchment geology, climate, and vegetation affect the acid-base status of lakes through time. In cool humid regions of northeastern US, the dominant trend in diatom species composition in lakes on crystalline bedrock is a progressive decrease in $\mathrm{pH}$ over time. This trend may reflect the loss of base cations during weathering and the increase in DOC inputs as vegetation density increased, particularly of conifers (Ford 1990; Whitehead et al. 1989). In the maritime regions of southeastern Alaska, high precipitation $\left(>1,500 \mathrm{~mm}_{\text {year }}^{-1}\right.$ ) leads to podzolization of soils and peatland expansion in areas of low elevation. As a result, even lakes on calcareous glacial till show long-term declines in lake $\mathrm{pH}$ (Engstrom et al. 2000; Fritz et al. 2004).
In high-latitude regions of Scandinavia, paleolimnological records from sites on base-poor bedrock also show a decline in $\mathrm{pH}$ over time, in most cases associated with increased terrestrial plant biomass and acidification of catchment soils. In contrast, in nearby sites on base-rich substrates, catchment vegetation was relatively stable during the early to midHolocene (Bigler et al. 2003), and similarly no major change is evident in the aquatic flora, although undoubtedly climate varied substantially over multiple millennia. A similar pattern of stasis in diatom community composition over multiple millennia is also observed in paleolimnological records from the alpine steppe of Siberia (Westover et al. 2006).

In regions proximal to the forest-tundra boundary, DOC export may vary with climate and produce fluctuating limnological trajectories. For example, in eastern Canada, a warmer and moister climate in the mid-Holocene enabled the northward movement of boreal forest into tundra. As a result, the build-up of organic-rich soils enhanced both DOC and nutrient inputs into regional lakes (Pienitz et al. 1999). As the climate cooled and tree line moved south, productivity and DOC concentrations declined. Similar patterns of change have been observed in the Eurasian Arctic (Jones et al. 2011). In both of these studies, ma- 
jor limnological change was associated with climatedriven impacts mediated through the catchment.

In arctic lakes of West Greenland, the long-term limnological trajectory is of gradual change along an axis from high $\mathrm{pH}$ to lower values over time, but with varied timing and rate (Perren et al. 2012). This common trajectory yet variable rate among sites suggests the major role of time-dependent catchment processes, such as the long-term leaching of base cations and increased transfer of organic acids, in affecting changes in ecosystem state (Table 1 ).

Boyle (2007) evaluated the relative roles of abiotic versus biotic processes as drivers of long-term lake acidification by modeling the concentration of mineral phases in runoff during the weathering of granite. Because the time-dependent loss of apatite via chemical weathering effectively tracks the magnitude and rate of long-term acidification reconstructed in multiple paleoecological studies from boreal latitudes of Europe and North America, Boyle concluded that abiotic processes (weathering) are more important than vegetation impacts on DOC and soil development in regulating early interglacial acidification. The model predicts that changes in mean annual runoff and soil thickness have significant impacts on longterm leaching rates, whereas the impact of DOC concentration is limited.

In some regions of the Canadian Arctic, longterm lake acidification is not caused by the loss of basecations over time, based on the lack of correlation between diatom-inferred $\mathrm{pH}$ and sediment geochemical measurements (Wilson et al. 2012). In these settings long-term acid-base chemistry is apparently climate driven, such that the higher productivity and $\mathrm{CO}_{2}$ uptake associated with warm intervals increased lake $\mathrm{pH}$, whereas during cold periods reduced productivity and reduced evasion of $\mathrm{pH}$ to the atmosphere because of ice cover caused $\mathrm{pH}$ to decline (Michelutti et al. 2007; Wolfe 2002). In this setting, long-term $\mathrm{pH}$ decline during the Holocene is attributed to Neoglacial cooling rather than to catchment processes. These sites are all in areas characterized by cold-based and nonerosive glaciation, which preserved relict landscapes through several glacial cycles and produced surfaces with little accumulation of till. As a result the role of soil development and vegetation change in driving long-term $\mathrm{pH}$ changes is limited (Wilson et al. 2012).
Trajectories of change in nutrient status and productivity following deglaciation

A dominant influence of catchment successional processes and vegetation change on lake ecosystems is evident during the first few millennia following deglaciation throughout temperate and highlatitude sites in the Northern Hemisphere. In the Arctic, benthic algal communities dominated following deglaciation, likely developed as a result of low nutrient concentrations associated with unstable and weakly developed catchment soils (Bigler et al. 2002, 2003; Birks et al. 2000; Bradshaw et al. 2000; Perren et al. 2012). In sub-arctic lakes of Sweden and Norway during the late-glacial period (Bigler et al. 2002, 2003; Birks et al. 2000; Bradshaw et al. 2000), increased benthic diatom diversity and fluctuations between benthic and planktic diatoms are associated with changes in nutrient input from the catchment and clastic load rather than directly with fluctuations in temperature or precipitation. Strong catchment influences continue into the early and mid-Holocene at most sites, but the magnitude, nature, and rate of influence are strongly influenced by catchment geology and elevation.

In temperate latitudes in regions with moderate to high precipitation in the period following deglaciation, catchment processes also are a primary control on lake ecosystem state immediately following lake formation. Diatom assemblages and pigment data from various temperate sites in North America and Europe indicate that primary production was low in the first centuries to millennia following deglaciation, but as the catchment stabilized and during the initial phases of weathering and soil formation, planktic floras developed and production increased, which suggests higher nutrient concentrations in the water column (Bennett et al. 2001; Florin 1970; Haworth 1976; Laird et al. 1998; Lotter 2001; Norton et al. 2011). The rate of change in nutrient concentration and primary production is likely highly variable among sites, dependent on site-specific differences in geology and vegetation history (Fritz et al. 2004) (Figure 2). Unfortunately the temporal resolution of most late-Glacial stratigraphic records is not sufficiently high to clearly establish rates of change.

Evaluating the role of nitrogen limitation in the early ontogeny of boreal and arctic ecosystems is 
complicated by in-lake successional processes, because nitrogen-fixing cyanobacteria can dominate in early stages after deglaciation, possibly because of their preference for alkaline conditions and their ability to use $\mathrm{HCO}_{3}$ as well as fix $\mathrm{N}_{2}$ directly (Reynolds 2006). This is suggested in pigment records from lakes in SW Greenland, where cyanobacterial pigments are dominant immediately after lake formation and subsequently decline, perhaps because the net nitrogen subsidy from land increased in-lake nitrogen availability (Anderson et al. 2008; McGowan et al. 2008). It is unclear whether these pigments are associated with picophytoplankton or benthic cyanobacterial mats. In many arctic lakes, Nostoc colonies are common in the littoral zone, and presumably their presence (and decay) increases nitrogen availability locally within the benthos. One likely beneficiary of this locally fixed nitrogen is benthic diatoms, which are abundant in arctic and boreal lakes; primary production in Arctic lakes is commonly concentrated in the littoral zone (Vadeboncoeur et al. 2003).

Although long-term Holocene oligotrophication is predicted in theoretical terms by declining apatite abundance during weathering (Boyle 2007), relatively few studies clearly demonstrate declining nutrient concentrations over time independent of long-term acidification. At a site in European Russia, maximum organic carbon content of the sediments (a gross measure of system productivity) occurred in the oldest sediments, yet diatom accumulation rates were uniform throughout the early to mid Holocene and did not decline until around 3,000 year BP, when catchment vegetation switched from forest to tundra and planktonic diatoms increased (Jones et al. 2011). In the early history of a site inSWGreenland, both planktic diatoms and cyanobacterial pigmentswere abundant suggesting enhanced productivity, and subsequently declined. Yet planktic diatoms return intermittently later, which suggests other controls on planktic production (Anderson et al. 2008). As suggested above, cyanobacterial dominance during early lake development may reflect high $\mathrm{pH}$ and inorganic forms as much as nutrient concentrations. In Glacier Bay (Alaska, USA) temporal trends in diatom production follow changes in catchment derived $\mathrm{N}$ inputs associated with nitrogen-fixing vegetation rather than longterm trends driven by weathering (Engstrom and Fritz 2006; Fritz et al. 2004).

Because of the high dry-mass accumulation rates during the early phases of catchment ontogeny (due to slope instability, low vegetation cover, etc.) and associated dilution effects on the sediment matrix, organicmatter, carbon content or biogenic silica should be presented as accumulation rates. For example, Anderson et al. (2012) compared C accumulation rates for four lakes in Greenland; at none of the sites were $\mathrm{C}$ accumulation rates at their maximumduring the earliest periods of lake development but instead occurred later due a range of to climate-catchment mediated processes. A more systematic assessment of lake productivity trends (using biogenic silica and/ or carbon accumulation rates together with pigment analyses) over a range of sites is required to evaluate more critically the concept of long-term oligotrophication, as opposed to qualitative inferences from diatom assemblages where thecommunity changes can be interpreted in a number of different ways.

\section{Direct climate versus catchment influences in affecting planktic diatom floras}

Both direct climate influences and catchment-mediated processes have been posited to play a role in the development of planktic diatom floras in arctic and alpine lakes. A common feature in arctic lake records of moderate depth is a Holocene expansion of planktic diatoms, particularly in the genus Cyclotella. This expansion has been related to direct climate impacts on lake thermal structure and to altered nutrient inputs, particularly of nitrogen. In a large lake below tree line in Sweden, for example, the expansion of a Cyclotella flora during the early Holocene is attributed to both catchment-controlled nutrient inputs, as well as climate conditions suitable for the development of summer stratification (Bigler et al. 2002). Cyclotella comensis declined with the expansion of Pinus in the catchment around $7500 \mathrm{cal} \mathrm{yr} \mathrm{BP}$ as the C. rossii complex increased, and Cyclotella glomerata (=Discotella pseudostelligera complex) was periodically important $(>20 \%)$. In a lake in the southern Yukon (Chakraborty et al. 2010), the replacement of Cyclotella ocellata by Cyclotella pseudostelligera around $7000 \mathrm{cal} \mathrm{yr}$ $\mathrm{BP}$ is attributed to insolation-driven changes in thermal structure.

In the low arctic lakes of West Greenland, planktic diatoms in the genus Cyclotella replace pioneering benthic taxa in the early Holocene in coastal areas but in the late-Holocene period in lakes further inland, an area that was deglaciated much later (Per- 
ren et al. 2012). At the coastal site (SS49), the transition from benthic to planktic taxa could be a response to increased in-lake nutrient concentrations associated with weathering and soil development driven by Holocene climate warming, as well as to the development of a stratified water column. A possible role for greater in-lake nitrogen availability associated with the build of the ecosystem nitrogen pool is suggested by the close relationship between the abundance of C. pseudostelligera and \% TN in the lake sediments (Figure 3). Sedimentary nitrogen is reactive and interpreting it directly in terms of nutrient availability has to be done with care. Likewise, it is not clear whether or not lake thermal structure influenced planktic diatom species composition; in any case, significant roles for nutrients and for stratification are not mutually exclusive. In the inland sites, the late-Holocene expansion of $\mathrm{Cy}$ clotella species cannot be attributed to warming, because it occurs at the onset of cooler and moister regional climate (Aebly and Fritz 2009); potential explanations include changes in nutrient loading either through direct climate impacts on watercolumn mixing or via indirect climate impacts on catchment-driven nutrient loading. At SS16, for example, the diatom and macrofossil records suggest a benthic-dominated lake in the early to mid Holocene (Heggen et al. 2010; Perren et al. 2012), possibly because nutrients were trapped or recycled in the littoral zone and were insufficient to support planktic diatoms. From $\sim 4,000$ cal year BP, with onset of Neoglacial cooling, however, diatom productivity increased dramatically, Cyclotella species expanded, macrophyte community structure changed with the reduced abundance of Myriophyllum and Potamogeton spp. (Fig 3), and shrub tundra started to contract (Heggen et al. 2010). The nitrogen content of glaciers is now known to be considerable (Hodson et al. 2008), and the extent to which $\mathrm{N}$ within the glacial system is transferred to local terrestrial and aquatic ecosystems remains unclear. None-the-less, at the time of Cyclotella expansion, eolian activity increased dramatically in inland areas proximal to the ice sheet (Willemse et al. 2003), with widespread loess deposition across the landscape, derived from glacial outwash. Dust can contain high concentrations of minerals and nutrients (Neff et al. 2008; Psenner 1999). Thus, increased nutrient (N) loading via dust may have enhanced lake productivity and fostered Cyclotella expansion. At another inland lake in West Greenland (SS2), Cyclotella pseudostelligera

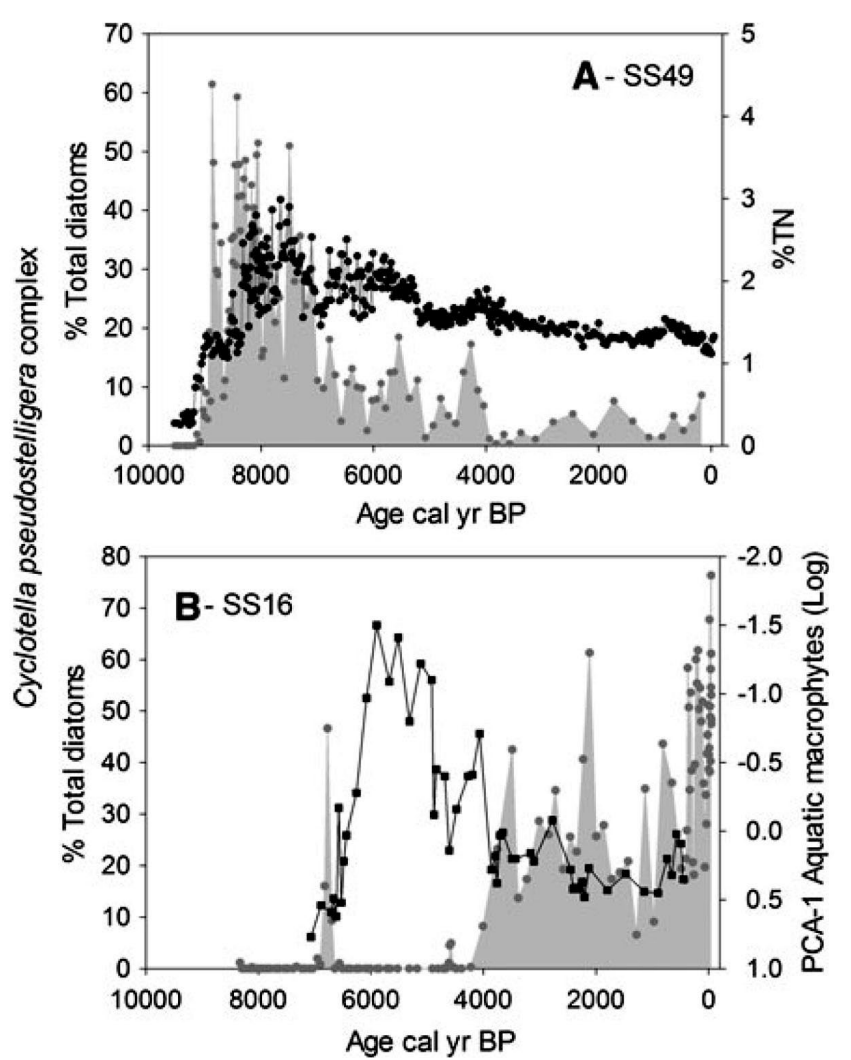

Figure 3. Core trajectories for two lakes in West Greenland: a) the relationship between total nitrogen content and Cyclotella relative abundance in a coastal lake (SS49) (original data from Perren et al. 2012); b) the inverse relationship between changing ecological structure of the macrophyte community as PCA axis 1 (which reflects the changing abundance of Myriophyllum and Potamogeton spp) and Cyclotella percentage in an inland lake (SS16) (original data from Perren et al. 2012; Heggen et al. 2010). Cyclotella is the grey shade in both plots.

is present, albeit intermittently, from the mid-Holocene onward (Anderson et al. 2008), and a similar pattern occurs at Raffles Lake on east Greenland. Both may be associated with external nutrient input and Neoglacial cooling (Cremer et al. 2001).

An expansion of Cyclotella species also has been observed in multiple arctic and alpine lake records spanning the last century or so and has been variably attributed to the impacts of warming on lake mixing depth and to enhanced atmospheric nitrogen deposition. For example, Rühland et al. (2008) rejected nutrient dynamics as a mechanism for the widespread recent increase in small Cyclotella species in arctic and alpine lakes. However, Saros et al. (2012), using a combination of experimental and paleolimnological approaches, suggest that a dynamic interplay of light, thermal stratification, and nitro- 
gen availability affect Cyclotella dominance in several alpine lakes in North America. Small Cyclotella assemblages are an important component of many lakes located close to the ice margin in Greenland today (Perren et al. 2009), a climatically cool area but with considerable loess deposition associated with strong katabatic winds. As we review above, paleolimnological evidence suggests that in many systems Cyclotella assemblages have been present for centuries, sometimes supported by a combination of external nutrient supply and mixing regimes. This long-term perspective suggests that both catchment mediated processes, such as DOM export and changing catchment-driven nutrient loading, as well as direct climate impacts on thermal and hydrological budgets may affect Cyclotella abundance over a range of timescales.

\section{Strong climate-driven influences on lacustrine ecosystems}

Changes in nutrient delivery to lakes associated with early ecosystem succession play a dominant role in most lakes in glaciated terranes, but the subsequent trajectory of ecosystem change in temperate latitudes seems to vary dependent on climate, elevation, and catchment geology. In alpine regions with moderate to high base status and where paludification is uncommon, climate may play a more substantive role in limnological change. In the Alps, for example, the date of the onset of isothermal mixing in the autumn is correlated with changes in diatom assemblage composition in a contemporary calibration data set, and a transfer function derived from these data has been successfully applied to reconstruct past climate variation from lacustrine diatom assemblages (Schmidt et al. 2004). In another hardwater lake on the Swiss Plateau, the development of a forested landscape in the early Holocene fostered meromixis and the stable dominance of a Cyclotella flora into the mid-Holocene (Lotter 2001). Yet within this interval were periods when enhanced water column mixing or changes in lake level were the primary influence on higher frequency changes in species composition. Similarly, in many alpine lakes in western North America, changes in the strength and duration of water-column mixing are the primary control on lacustrine nutrient concentrations and on diatom species assemblages (Chakraborty et al. 2010, Gavin et al. 2011; Whitlock et al. 2012).
In sub-humid to semi-arid areas of the mid-latitudes (precipitation $<\sim 500 \mathrm{~mm}$ year ${ }^{-1}$ ), even in mountainous terrane, climate is the dominant impact on lake ecosystem structure and function. Thus, changes in ecosystem state are most commonly associated with changes in effective moisture (precipitation minus evaporation) and its impacts on lake level and ionic concentration (Table 1) (Fritz et al. 2010). In parts of northwestern North America, for example, even the pioneering stages of lake development were under the strong influence of climate. High summer insolation in the late-Glacial period promoted rapid wastage of the continental ice sheets, and the lakes formed by the retreating ice often were dry or shallow and sometimes saline, because of high growing season temperature and evaporation (Fritz et al. 2000; Stone and Fritz 2006). In both forested and grassland sub-humid to semi-arid areas of the North American mid-continent, most fluctuations in diatom community structure are clearly driven by changes in lake depth and ionic concentration (Bennett et al. 2001; Fritz et al. 2010; Stone and Fritz 2006). Although both depth and ionic concentration may affect diatoms via their influence on nutrient availability (Saros and Fritz 2000), the changes in biogeochemical cycling are a result of direct climate impacts on the lake environment rather than climate effects that are mediated through catchment processes.

\section{Conclusions}

Catchment processes are universally important in the first centuries to millennia of limnological development as the landscape stabilizes and as weathering and early soil development generate higher biogeochemical fluxes from the catchment to the lake. The increased nutrient flux drives increased algal production, and, in lakes where depth and climate are suitable for the development of plankton, shifts from benthicdominated to planktic floras occur.

Subsequently the relative roles of catchment processes in mediating limnological change are a function of catchment geology, elevation, vegetation, and climate setting (Figure 1). In most parts of the Arctic and in boreal regions, $\mathrm{pH}$ decline is the dominant trajectory of change. This is driven primary by catchment processes in base-poor terranes or in climate settings that favor the build-up of organic-rich soils and subsequent podzolization. However, in some parts of the Canadian Arctic, $\mathrm{pH}$ decline over time is 
apparently mediated by climate impacts on productivity and lake-atmosphere $\mathrm{CO}_{2}$ exchange, because the accumulation of surface tills and subsequent soil development is limited. In some arctic and alpine regions with moderate concentrations of base cations, planktic assemblages, often dominated by Cyclotella species, ultimately develop and persist for millennia, supported by a combination of external nutrient supply and patterns of thermal stratification. Long-termacidification driven by changes in vegetation and soils also is common in temperate latitudes with cool humid climate and base-poor substrates. But in humid regions on soils with moderate to high base concentrations, changes in nutrients and light are the most common drivers of changes in diatom species composition, associated primarily with the strength and duration of water-column mixing and secondarily with catchment processes that affect DOC and nutrient export. Climate impacts on aquatic structure and function are most pronounced in semi-arid and arid regions where lakes undergo pronounced shifts in lakelevel and in ionic concentration.

All geographic areas where long-term changes in lacustrine ecosystem state have been reconstructed from multiple sites show considerable variation among sites (Figure 2). In some cases, such as Glacier Bay, Alaska, the differences are attributed to variability in the early plant species that colonized specific regions and their impact on catchment nitrogen cycling (Fritz et al. 2004). In sub-alpine areas of northern Sweden, differences in pattern of change are correlated with geologic differences, specifically the mineralogy of parent bedrock (Bigler et al. 2002). In an Arctic transect, the chemistry and hence biotic assemblages in the lakes in the semi-arid region adjacent to the Greenland ice sheet are influenced by alkalinity changes and eolian activity during dry intervals, whereas lakes in humid coastal areas do not have this influence (Perren et al. 2012). The role of catchment processes in producing regional heterogeneity in paleolimnological studies indicates the need for more widespread use of multiple sites (i.e. regionally replicated studies) when using lake sediment records for reconstructing past climate (Fritz 2008; Kaufman 2012). The prominent role of localscale processes in mediating the impact of climate on lacustrine biotic communities and lakewater chemistry serves to emphasize the critical role of ecosystem processes in affecting lake structure and function (cf Lantz et al. 2010). Lake sediments from temperate, boreal, and arctic landscapes affected by glaciation undoubtedly reflect climate (Figure 1), but a greater understanding of the catchment filter and in-lake processes will enhance attempts to extract the climate signal from paleolimnological records.

Acknowledgments - This manuscript is dedicated to Rick Battarbee, who was instrumental in catalyzing each of our interests in diatoms and lakes. We also acknowledge Dan Engstrom for many discussions over the years on lake ontogeny. We are grateful to Bianca Perren and Hilary Birks for providing their data from SS16 and SS49, which are plotted in Figure 3. The preparation of this manuscript was funded in part by NSF EAR08-16576 to Fritz.

\section{References}

Aebly FA, Fritz SC (2009) Paleohydrology of Kangerlussuaq West Greenland during the last $\sim 8,000$ year. Holocene 19:91-104

Anderson NJ, Leng MJ (2004) Increased aridity during the early Holocene in West Greenland inferred from stable isotopes in laminated-lake sediments. Quat Sci Rev 23:841-849

Anderson NJ, Bugmann H, Dearing JA, Gaillard M-J (2006) Linking palaeoenvironmental data and models to understand the past and to predict the future. Trends Ecol Evol 21:696-704

Anderson NJ, Brodersen KP, Ryves DB, McGowan S, Johansson LS, Jeppesen E, Leng MJ (2008) Climate versus in-lake processes as controls on the development of community structure in a low-arctic lake (South-West Greenland). Ecosystems 11:307-324

Anderson NJ, Liversidge AC, McGowan SM (2012) Lake and catchment response to Holocene environmental change: spatial variability along a climate gradient in southwest Greenland. J Paleolimnol 48:209-222

Bakke J, Lie O, Nesje A, Dahl SO, Paasche O (2005) Utilizing physical sediment variability in glacier-fed lakes for continuous glacier reconstructions during the Holocene, northern Folgefonna, western Norway. Holocene 15:161-176

Battarbee RW (1991) Recent paleolimnology and diatombased environmental reconstruction. In: Shane LCK, Cushing EJ, eds., Quaternary landscapes. University of Minnesota Press, Minneapolis, pp 129-174

Battarbee RW (2000) Palaeolimnological approaches to climate change, with special regard to the biological record. Quat Sci Rev 19:107-124

Battarbee RW, Monteith DT, Juggins S (2005) Reconstructing pre-acidification $\mathrm{pH}$ for an acidified Scottish loch: a comparison of palaeolimnological and modeling approaches. Environ Pollut 137:135-149

Bennett JR, Cumming BF, Leavitt PR, Chiu M, Smol JP, Szeicz J (2001) Diatom, pollen, and chemical evidence of 
postglacial climatic change at Big Lake, South-central British Columbia, Canada. Quat Res 55:332-343 J Paleolimnol (2013) 49:349-362 359

Berner EK, Berner RA (2012) Global environment: Water, air and geochemical cycles, 2nd edn. Princeton University Press, Princeton

Bigler C, Larocque I, Peglar SM, Birks HJB, Hall RI (2002) Quantitative multi-proxy assessment of long-term patterns of Holocene environmental change from a small lake near Abisko, northern Sweden. Holocene 12:481-496

Bigler C, Grahn E, Larocque I, Jeziorski A, Hall R (2003) Holocene environmental change at Lake Njulla (999 m a.s.l.), northern Sweden: A comparison with four small nearby lakes along an altitudinal gradient. J Paleolimnol 29:13-29

Birks HJB (1997) Reconstructing environmental impacts of fire from the Holocene sedimentary record. In: Clark JS, Cachier H, Goldammer JG, Stocks B, eds., Sediment records of biomass burning and global change. Springer, Berlin

Birks HH, Birks HJB (2006) Multi-proxy studies in palaeolimnology. Veg Hist Archaeobot 15:235-251

Birks HH, Battarbee RW, Birks HJB (2000) The development of the aquatic ecosystem at Kråkenes Lake, western Norway, during the late-glacial and early-Holocene-A synthesis. J Paleolimnol 23:91-114

Boyle JF (2007) Loss of apatite caused irreversible early-Holocene lake acidification. Holocene 17:543-547

Bradshaw E, Jones VJ, Birks HJB, Birks HH (2000) Diatom responses to late-glacial and early Holocene environmental changes at Kråkenes Lake, western Norway. J Paleolimnol 23:21-34

Chakraborty K, Finkelstein SA, Desloges JR, Chow NA (2010) Holocene paleoenvironmental changes inferred from diatom assemblages in sediments of Kusawa Lake, Yukon Territory, Canada. Quat Res 74:15-22

Chapin FS III, Beldsoe CS (1992) Nitrogen fixation in arctic plant communities. In: Chapin FS III, Jeffries R, Reynolds R, Shaver GR, Svoboda J, eds., Arctic ecosystems in a changing climate: An ecophysiological perspective. Academic Press, New York, pp 301-320

Chapin FS, Walker LR, Fastie CR, Sharman LC (1994) Mechanisms of primary succession following deglaciation at Glacier Bay, Alaska. Ecol Monogr 64:149-175

Coolen MJL, Overmann J (1998) Analysis of subfossil molecular remains of purple sulfur bacteria in a lake sediment. Appl Environ Microbiol 64:4513-4521

Cremer H, Wagner B, Melles M, Hubberten HW (2001) The postglacial environmental development of Raffles So, East Greenland: inferences from a 10,000 year diatom record. J Paleolimnol 26:67-87

Dearing JA (1991) Lake sediment records of erosional processes. Hydrobiologia 214:99-106
Engstrom DR, Fritz SC (2006) Coupling between primary terrestrial succession and the trophic development of lakes at Glacier Bay, Alaska. J Paleolimnol 35:873-880

Engstrom DR, Wright HE (1984) Chemical stratigraphy of lake sediments as a record of environmental change. In: Haworth EY, Lund JWG, eds., Lake sediments and environmental history. University of Minnesota Press, Minneapolis, pp 11-67

Engstrom DR, Fritz SC, Almendinger JE, Juggins S (2000) Chemical and biological trends during lake evolution in recently deglaciated terrain. Nature (Lond) 408:161-166

Fee EJ, Hecky RE, Kasian SEM, Cruikshank DR (1995) Effects of lake size, water clarity, and climatic variability on mixing depths in Canadian Shield lakes. Limnol Oceanogr 41:912-920

Filippelli G, Souch C (1999) Effects of climate and landscape development on the terrestrial phosphorus cycle. Geology 27:171-174

Florin MB (1970) Late-glacial diatoms of Kirchner Marsh, southeastern Minnesota. Nova Hedwigia Beih 31:667-756

Ford MSJ (1990) A 10,000-yr. history of natural ecosystem acidification. Ecol Monogr 60:57-89

Fritz SC (2008) Deciphering climatic history from lake sediments. J Paleolimnol 39:5-16

Fritz SC, Metcalfe SE, Dean W (2000) Holocene climate patterns in the Americas from paleolimnological records. In: Markgraf V, ed., Interhemispheric climate linkages. Academic Press, New York, pp 241-263

Fritz SC, Juggins S, Engstrom DR (2004) Patterns of early lake evolution in boreal landscapes: A comparison of stratigraphic inferences with a modern chronosequence in Glacier Bay, Alaska. Holocene 14:828-840

Fritz SC, Cumming BF, Gasse F, Laird KR (2010) Diatoms as indicators of hydrologic and climatic change in saline lakes. In: Smol JP, Stoermer EF, eds., The diatoms: Applications to environmental and earth sciences, 2nd edn. Cambridge University Press, London, pp 186-208

Gavin DG, Henderson AC, Westover KS, Fritz SC, Walker IR, Leng MJ, Hu FS (2011) Abrupt Holocene climate change and potential response to solar forcing in western Canada. Quat Sci Rev 30:1243-1255

Goldman CR (1961) The contribution of alder trees (Alnus tenuifolia) to the primary productivity of Castle Lake, California. Ecology 42:282-288

Hall K, Thorn CE, Matsuoka N, Prick A (2002) Weathering in cold regions: Some thoughts and perspectives. Prog Phys Geog 26:577-603

Hasholt B, Søgaard H (1978) Et forsøg på en klimatisk-hydrologisk regionsinddeling af Holsteinborgs Kommune (Sisimiut). Geografisk Tidsskrift 77:72-92

Haworth EY (1976) Two late-glacial (Late Devensian) diatom assemblage profiles from northern Scotland. New Phytol 77:227-256 
Heggen MP, Birks HH, Anderson NJ (2010) Long-term ecosystem dynamics of a small lake and its catchment in West Greenland. Holocene 20:1207-1222

Hobbie SE, Nadelhoffer JK, Hogberg P (2002) A synthesis: The role of nutrients as constraints on carbon balances in boreal and arctic regions. Plant Soil 242:163-170

Hodson A, Anesio AM, Tranter M, Fountain A, Osborn M, Priscu J, Laybourn-Parry J, Sattler B (2008) Glacial ecosystems. Ecol Monogr 78:41-67

Hu F, Finney B, Brubaker LB (2001) Effects of Holocene Alnus expansion on aquatic productivity, nitrogen cycling, and soil development in southwestern Alaska. Ecosystems 4:358-368

Iverson J (1964) Retrogressive vegetation succession the postglacial. J Ecol 52:59-70

Jones JB, Petrone KC, Finlay JC, Hinzman LD, Bolton WR (2005) Nitrogen loss from watersheds of interior Alaska underlain with discontinuous permafrost. Geophys Res Lett 32:L02401. doi:10.1029/2004GL021734

Jones VJ, Solovieva N, Self AE, McGowan S, Rosen P, Salonen JS, Seppa H, Valiranta M, Parrott E, Brooks SJ (2011) The influence of Holocene tree-line advance and retreat on an arctic lake ecosystem: a multi-proxy study from Kharinei Lake, North Eastern European Russia. J Paleolimnol 46:123-137

Juggins S (2013) Quantitative reconstructions in palaeolimnology: new paradigm or sick science? Quat Sci Rev (in press)

Karlsson J, Bystrom P, Ask J, Ask P, Persson L, Jansson M (2009) Light limitation of nutrient-poor lake ecosystems. Nature (Lond) 460:506-509

Kaufman DS (2012) Introduction to the JOPL Special Issue, "Holocene paleoenvironmental records from Arctic lake sediment". J Paleolimnol 41:1-8

Laird KR, Fritz SC, Grimm E, Cumming BF (1998) Early Holocene limnological and climatic variability in the northern Great Plains. Holocene 8:275-285

Lantz TC, Gergel SE, Kokelj SV (2010) Spatial heterogeneity in the shrub tundra ecotone in the Mackenzie Delta Region, Northwest Territories: implications for arctic environmental change. Ecosystems 13:194-204

Leavitt PR, Fritz SC, Anderson NJ, Baker PA, Blenkner T, Bunting L, Catalan J, Conley D, Hobbs W, Jeppesen E, Korhola A, McGowan S, Rühland K, Rusak J, Solovieva N, Werne J (2009) Paleolimnological evidence for the effects on lakes of energy and mass transfer by climate and humans. Limnol Oceanogr 54:2330-2348

Lotter AF (2001) The palaeolimnology of Soppensee (Central Switzerland), as evidenced by diatom, pollen, and fossilpigment analyses. J Paleolimnol 25:65-79

Lotter AF, Anderson NJ (2012) Limnological response to environmental changes at inter-annual to decadal timescales. In: Birks HJB, Lotter AF, Juggins S, Smol JP, eds., Data handling and numerical techniques. Springer, Berlin

McGowan S, Juhler RK, Anderson NJ (2008) Autotrophic response to lake age, conductivity and temperature in two West Greenland lakes. J Paleolimnol 39:301-317

Michelutti N, Wolfe AP, Briner JP, Miller GH (2007) Climatically controlled chemical and biological development in Arctic lakes. J Geophy Res 112:(no. G3)

Neff JC, Ballantyne AP, Farmer GL, Mahowald ML, Conroy JL, Landry CC, Overpeck JT, Painter TH, Lawrence CR, Reynold RL (2008) Increasing eolian dust deposition in the western United States linked to human activity. Nat Geosci 1:189-195. doi:10.1038/ngeo133

Norton SA, Perry RH, Saros JE, Jacobson GL, Fernandez IJ, Kopacek J, Wilson TA, San Clements MD (2011) The controls on phosphorus availability in a Boreal lake ecosystem since deglaciation. J Paleolimnol 46:107-122

Odgaard BV (1993) Wind-determined sediment distribution and Holocene sediment yield in a small, Danish, kettle lake. J Paleolimnol 8:3-13

Perren BB, Douglas MSV, Anderson NJ (2009) Diatoms reveal complex spatial and temporal patterns of recent limnological change in West Greenland. J Paleolimnol 42: 233-247

Perren B, Anderson NJ, Douglas M, Fritz SC (2012) The influence of temperature, moisture, and eolian activity on Holocene lake development in West Greenland. J Paleolimnol 48:223-239. doi:10.1007/s10933-012-9613-6

Pienitz R, Smol JP, MacDonald GM (1999) Paleolimnological reconstruction of Holocene climatic trends from two boreal treeline lakes, Northwest Territories, Canada. Arct Antarct Alp Res 31:82-93

Psenner R (1999) Living in a dusty world: airborne dust as a key factor for alpine lakes. Water Air Soil Pollut 112:217-227

Renberg I (1990) A 12,600 year perspective on the acidification of Lilla Oresjon, southwest Sweden. Philos Trans $R$ Soc Lond B Biol Sci 327:357-361

Reynolds CS (2006) Ecology of phytoplankton. Cambridge University Press, Cambridge 552 pp

Rosen P (2005) Total organic carbon (TOC) of lake water during the Holocene inferred from lake sediments and nearinfrared spectroscopy (NIRS) in eight lakes from northern Sweden. Biogeochemistry 76:503-516

Rühland K, Paterson AM, Smol JP (2008) Hemisphericscale patterns of climate-related shifts in planktonic diatoms from North American and European lakes. Glob Change Biol 14:1-15

Saros JE, Fritz SC (2000) Nutrients as a link between ionic concentration/composition and diatom distributions in saline lakes. J Paleolimnol 23:449-453

Saros JE, Stone JR, Pederson GT, Siemmons KEH, Spanbauer T, Schliep A, Cahl D, Williamson CE, Engstrom 
DE (2012) Climate-induced changes in lake ecosystem structure inferred from coupled neo- and paleo-ecological approaches. Ecology 93:2155-2164

Schmidt R, Kamenik C, Kaiblinger C, Hetzel M (2004) Tracking Holocene environmental changes in an alpine lake sediment core: Application of regional diatom calibration, geochemistry, and pollen. J Paleolimnol 32: 177-196

Seitzinger S, Harrison JA, Bohlke JK (2006) Denitrification across landscapes and waterscapes: A synthesis. Ecol Appl 16:2064-2090

Smol JP, Douglas MSV (2007) From controversy to consensus: making the case for recent climate change in the Arctic using lake sediments. Frontiers in Ecology and Environment 5:466-474

Sobek SLJ, Tranvik J, Cole JJ (2005) Temperature independence of carbon dioxide supersaturation in global lakes. Global Biogeochemical Cycles 19:GB2003,doi: 10.1029/ 2004GB002264

Spring S, Schulze R, Overmann J, Schleifer KH (2000) Identification and characterization of ecologically significant prokaryotes in the sediment of freshwater lakes: Molecular and cultivation studies. FEMS Microbiol Rev 24:573-590

Stefan HG, Fang X (1997) Simulated climate change effects on ice and snow covers on lakes in a temperate region. Cold Reg Sci Technol 25:137-152

Stone JR, Fritz SC (2006) Multi-decadal drought frequency and Holocene drought instability in the northern Rocky Mountains. Geology 34:409-412

Tape K, Sturm M, Racine C (2006) The evidence for shrub expansion in Northern Alaska and the Pan-Arctic. Glob Change Biol 12:686-702

Tye AM, Heaton THE (2007) Chemical and isotopic characteristics of weathering and nitrogen release in non-glacial drainage waters on Arctic tundra. Geochim Cosmochim Acta 71:4188-4205

Vadeboncoeur Y, Jeppesen E, Vander Zanden MJ, Schierup HH, Christoffersen K, Lodge DM (2003) From
Greenland to green lakes: Cultural eutrophication and the loss of benthic pathways in lakes. Limnol Oceanogr 48:1408-1418

Westover KS, Fritz SC, Blyakharchuk TA, Wright HE (2006) Diatom paleolimnological record of environmental change in the Altai Mountains, Siberia. J Paleolimnol 35:519-541

Whitehead DR, Charles DF, Jackson ST, Smol JP, Engstrom DR (1989) The developmental history of Adirondack (NY) lakes. J Paleolimnol 2:185-206

Whitlock C, Dean WE, Fritz SC, Stevens LR, Stone JR, Power MJ, Rosenbaum JR, Pierce KL, Bracht-Flyr B (2012) Holocene seasonal variability inferred from multiple proxy records from Crevice Lake, Yellowstone National Park, USA. Palaeogeogr Palaeoclimatol Palaeoecol 331-332: 90-103

Willemse NW, Koster EA, Hoogakker B, van Tatenhove FGM (2003) A continuous record of Holocene eolian activity in West Greenland. Quat Res 59:322-334

Williamson CE, Morris DP, Pace ML, Olson OG (1999) Dissolved organic carbon and nutrients as regulators of lake ecosystems: resurrection of a more integrated paradigm. Limnol Oceanogr 44:795-803

Williamson CE, Olson OG, Lott SE, Walker ND, Engstrom DR, Hargreaves BR (2001) Ultraviolet radiation and zooplankton community structure following deglaciation in Glacier Bay, Alaska. Ecology 82:1748-1760

Wilson CR, Michelutti N, Cooke CA, Briner JP, Wolfe AP, Smol JP (2012) Arctic lake ontogeny across multiple glacial cycles. Quat Sci Rev 31:112-126

Wolfe AP (2002) Climate modulates the acidity of Arctic lakes on millennial time scales. Geology 30:215-218

Wookey PA, Aerts R, Bardgett RD, Baptist F, Brathen KA, Cornelissen JHC, Gough L, Hartley IP, Hopkins DW, Lavorel S, Shaver GR (2009) Ecosystem feedbacks and cascade processes: understanding their role in the responses of Arctic and alpine ecosystems to environmental change. Glob Change Biol 15:1153-1172 